\title{
Truck Driver Falls from Tanker Truck to His Death
}

\section{Incident Number: 14KY021}

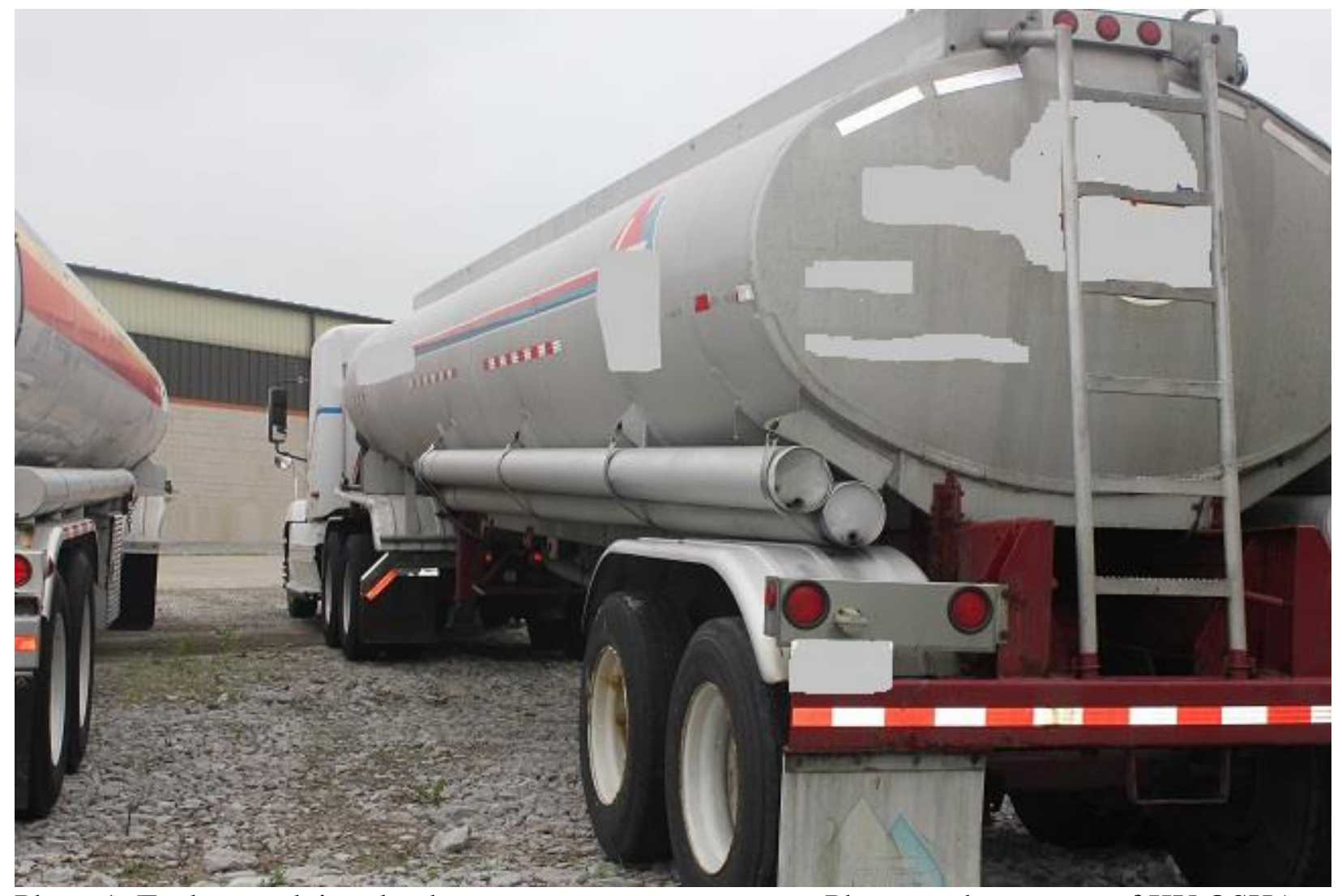

Photo 1: Tanker truck involved.

Photograph courtesy of KY OSHA

Kentucky Fatality Assessment and Control Evaluation Program Kentucky Injury Prevention and Research Center 333 Waller Avenue

Suite 242

Lexington, Kentucky 40504

Phone: 859-323-2981

Fax: 859-257-3909

www.kiprc.uky.edu

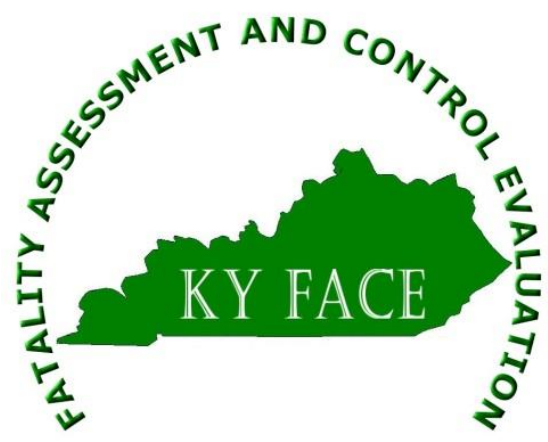




\section{Kentucky Fatality Assessment and Control Evaluation (FACE) Program Incident Number: 14KY021 \\ Release Date: February 2, 2015 \\ Subject: Truck Driver Falls off Tanker Truck to His Death}

\section{$\underline{\text { Introduction }}$}

On May 14, 2014, at 10:30 am, a 56-year-old tanker driver arrived at an oil distribution plant with 6,000 gallons of oil. He backed into the garage bay with the guidance of an employee at the distribution plant. The victim exited the cab, climbed onto the top of the tanker, and began the process of venting the oil tanker compartments. The employee was in the bay area, but the driver was not in his sightline. The employee heard the sound of the victim falling approximately 10 feet on to the concrete floor below, went to investigate the noise and found the victim injured on the ground. The oil plant employee then summoned help from other workers. EMS was notified and the victim was transported by helicopter to the nearest local trauma center where he died the following day.

To prevent future occurrences of similar incidents, the following recommendations have been made:

Recommendation No. 1: Employers requiring employees to access the top of tankers must provide adequate fall protection.

Recommendation No. 2: Employers should consider equipping their tanker trucks with rail systems, shown in photos 3 and 4.

\section{$\underline{\text { Employer }}$}

The employer was an out-of-state based bulk transportation leader with 75 years of distribution experience. The employer has 1,400 drivers, 6,000 trailers and 50 terminals across the U.S. The company began in 1936 .

\section{Written Safety Programs and Training}

The employer requires drivers to participate in a comprehensive training program, beginning with on-the-job training (OJT) in the particular cargo they will be transporting. OJT is a handson education process conducted by a certified driver trainer. Drivers learn the various procedures involving loading and unloading, as well as various equipment operation procedures of the tank trailer. The driver trainer also assesses trainees' skills as a professional driver during this time.

In addition to the OJT, drivers must attend a three day New Associates Orientation Program (NAOP) during the first 90 days of employment. This classroom-style training is instructed by their Regional Safety Managers. Drivers receive training in hazardous materials, defensive 
driving, hours of service, loading and unloading procedures, rollover prevention and other relevant subjects.

In addition to the OJT and NAOP, drivers also receive ongoing training on various subjects during the terminal's quarterly safety meetings. Safety topics as well as latest regulation updates from the Department of Transportation and Federal Motor Carrier Safety Administration are discussed. The employer holds open forum safety meetings to discuss all drivers' concerns.

Part of the victim's training included learning the pump unloading procedure. This procedure contained detailed steps to unload and load the product, including venting the tanks. However, the procedure in the MC 3-7/DOT 407 did not contain any procedures for accessing the top of the tankers to vent the compartments.

The victim was classified as a Level 1 Trainee, indicating that he had not hauled any of the products the company distributes in the last three years. The victim completed "in yard" exercises on April 22 and 23, 2014. Additionally, he had 4 full days of "training trips" with the driver-trainer on April $21^{\text {st }}-25^{\text {th }}, 2014$. This indicated the victim had successfully completed the required training.

\section{$\underline{\text { Equipment }}$}

The victim drove a "Fruehauf" tanker truck to the oil distribution center. The truck was identified as a "non-specification petro tank" with a capacity of 8,850 gallons of crude oil. It measured 9 feet 10 inches in height and 40 feet 4 inches in length. A walkway on top of the tanker measured 30 inches in width. Toe boards that ran the length of both sides of the walkway measured $71 / 2$ inches in height. The walkway's surface was slip-resistant with an emery board like matting. There were 5 compartments on the tanker, each equipped with a dome lid on top of the tanker. The dome lids were accessed by a ladder attached at the rear of the tanker. The truck was turned off and in a stationary position at the time of the incident.

\section{$\underline{\text { Victim }}$}

The victim was a 56-year-old white male who was hired into the company April 21, 2014. His occupation was truck driver. He had been employed with the company for twenty-three days. However, he had previous experience in his field and held a bachelor's degree.

\section{Incident Scene}

The incident occurred inside a 175,000 square foot warehouse equipped with several bays and a concrete floor. The victim had backed his tank into the warehouse to deliver the oil.

\section{Weather}

May 14, 2014 was a cloudy day with temperatures ranging from 71 to 80 degrees Fahrenheit. It is believed the weather was not a factor in the incident. 


\section{$\underline{\text { Investigation }}$}

The Kentucky Fatality Assessment and Control Evaluation Program was notified of an occupational fatality involving a truck driver by the Kentucky Labor Cabinet on May 16, 2014.

The victim left his out-of-state employer's truck terminal at 7:45 am on May 14, 2014, in his Fruehauf tanker truck. He was to travel 112 miles to deliver 6,000 gallons of crude oil to an oil distribution plant in Kentucky. The victim arrived at the oil distribution plant and checked in with the facility's gate guard at approximately 10:20 am. He then proceeded toward the warehouse bay area to deliver his 6,000 gallons of oil. With the assistance of another employee at the oil distribution plant, the victim backed his tanker into one of the open bays. The assisting employee then went about his duties as the victim exited his truck and began the process of venting the tanker compartments (Photo 2). While the other employee was in the bay area at the time of the incident, the victim was not in his line of sight. The employee responded to the sound of the victim falling approximately 10 feet to concrete floor below and he found the victim lying on the passenger's side of the tanker with injuries. The victim had fallen 9 feet, 10 inches to the concrete ground below. The employee immediately shouted for other workers to help; a call to 911 was placed at 10:28 am. When emergency medical services arrived at 10:34 am, they immediately called for a medical helicopter to airlift the victim to the nearest local trauma center where he died the following day.

No one witnessed the incident, so it is unclear whether the victim slipped climbing or fell traversing the top of the tanker. It is also unclear whether the victim's type II diabetic disease contributed to this incident. The victim died from his injuries on May 15, 2014 at 7:08 pm.

\section{Cause of Death}

The cause of death was subdural hemorrhage, blunt force trauma to head.

\section{$\underline{\text { Recommendations and Discussions }}$}

\section{Recommendation No. 1: Employers requiring employees to access the top of tankers must provide adequate fall protection.}

In compliance with OSHA 29 CFR 1910.23 (c) (1), open sided floors or platforms 4 feet or more above adjacent floor or ground levels must be guarded by a standard railing as specified in paragraph (e) (3). ${ }^{1}$ Manufacturers are now equipping tankers with bottom loading and automatic venting so that employees to negate the need for climbing on top of the tanker. The vapor vents automatically open during loading and unloading.

\section{Recommendation No. 2: Employers should consider equipping their tanker trucks with rail guarding systems.}

While a rail guarding system like the one shown in photo 4 costs approximately $\$ 10,000.00$, it can virtually save millions when it comes to employees falling to their death. There are several 
manufacturers that have a custom option of equipping the tanks with collapsible rail systems. ${ }^{2}$ Photo 3 show the tanker with the rail guarding system collapsed for when the tanker is in transport. Photo 4 shows the tanker with the rail system in place, ready for access by workers climbing to the top of the tanker. Employers who order new tankers should consider making this mandatory on all their tankers.

\section{Keywords}

Tankers

Falls

Tanker venting safety

Fall protection

Safety railing on tankers

\section{References}

${ }^{1} 29$ CFR 1910.23(c)(1)- Protection of open-sided floors, platforms, and runways. OSHA. [https://www.osha.gov/pls/oshaweb/owadisp.show_document?p_table=STANDARDS\&p_id=97 15] Accessed on September 20, 2014.

${ }^{2}$ Oilmen's offers aftermarket safety rail system for tank trucks, trailer. Bulk Transporter. [http://bulktransporter.com/hazmatsafety/oilmen-s-offers-aftermarket-safety-rail-system-tanktrucks-trailers] Accessed on September 20, 2014.

\section{Acknowledgements}

The Kentucky FACE program would like to thank the Labor Cabinet, KY OSHA, KMTA, and Usher Transport for their assistance with this report.

\section{The Kentucky Fatality Assessment \& Control Evaluation Program (FACE) is funded by} grant 2U600H008483-10 from the Centers for Disease Control and Prevention and the National Institute for Occupational Safety and Health. The purpose of FACE is to aid in the research and prevention of occupational fatalities by evaluating events leading to, during, and after a work related fatality. Recommendations are made to help employers and employees have a safer work environment. For more information about FACE and KIPRC, please visit our website: www.kiprc.uky.edu 


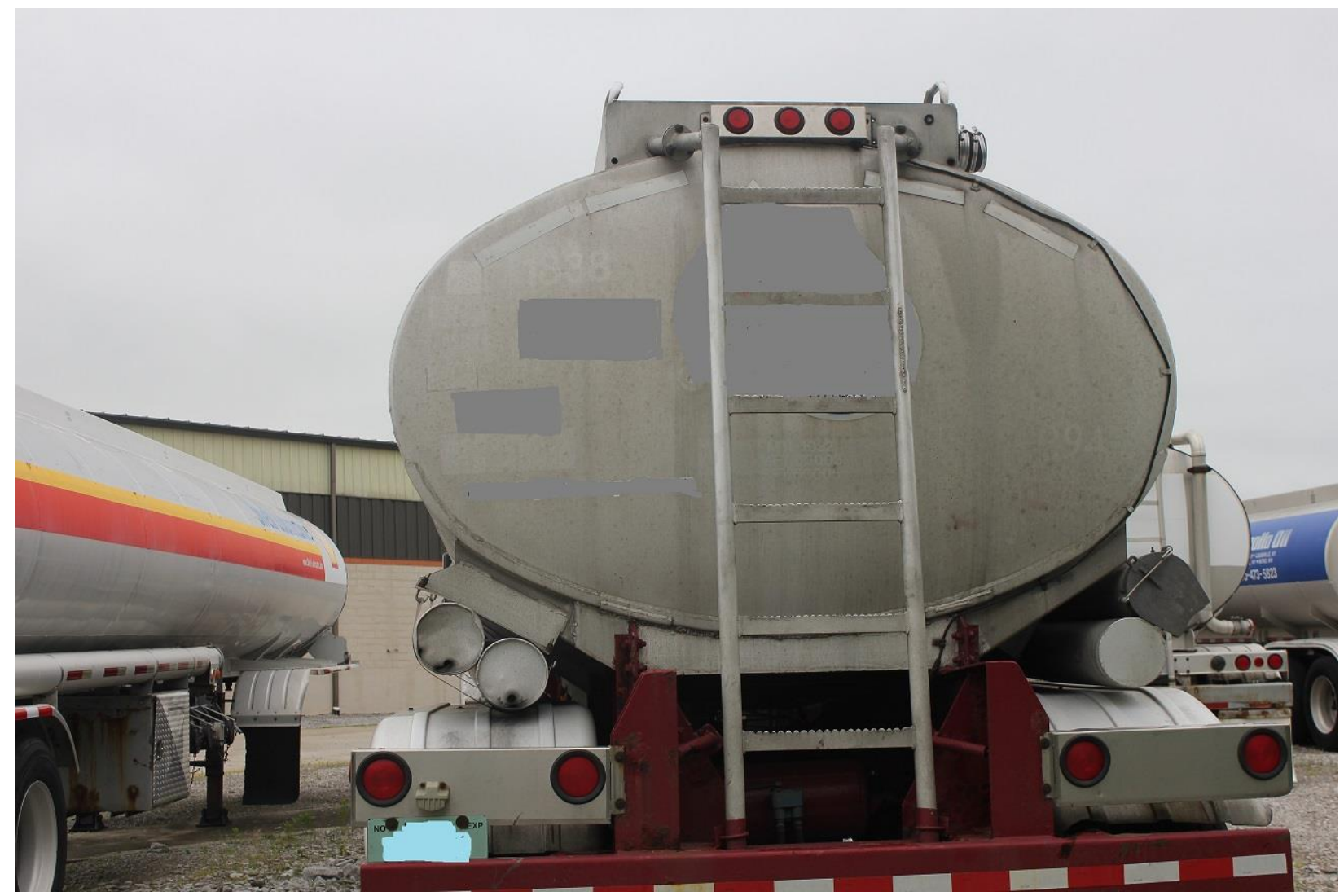

Photo 2 Rear of tank with ladder to reach compartments for venting. Photo courtesy of KY OSHA 


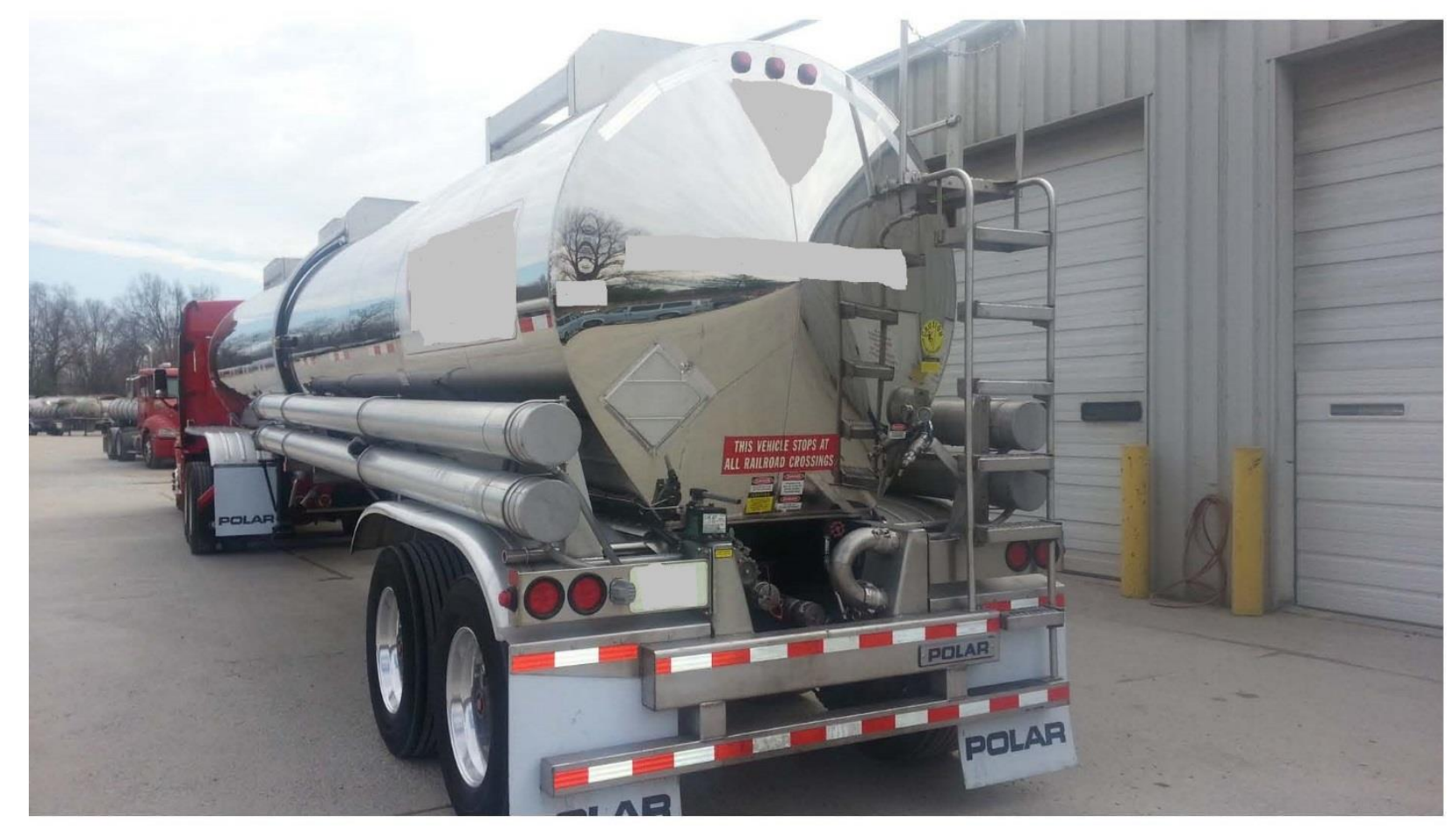

\section{PROACTIVE SAFETY STANDARDS TAKEN FOR NEW EQUIPMENT ORDERED OVER THE PAST YEAR - DRIVER FALL PROTECTION.}

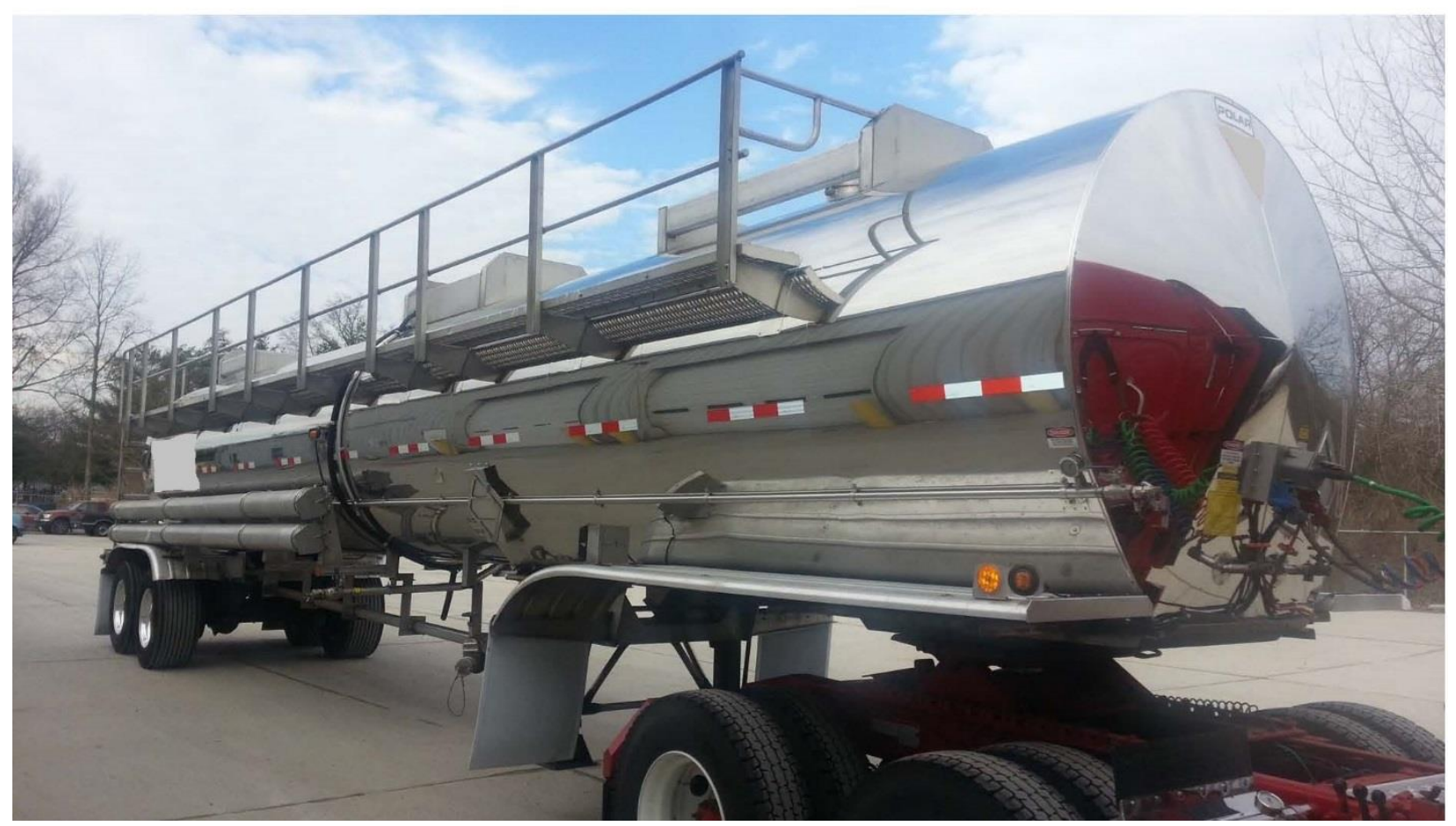

Photos 3 and 4 Courtesy of Usher Transportation 